\title{
Problemy zasilania współczesnych silników spalinowych wybranymi biopaliwami
}

\section{Wprowadzenie}

Obecnie ropa naftowa $\mathrm{i}$ jej pochodne są jednym z najpowszechniejszych źródeł energii. Prawie każda gałąź gospodarki opiera się w mniejszym lub większym stopniu na energii z niej uzyskiwanej i wykorzystywanej na różne sposoby. Doprowadziło to do sytuacji uzależnienia gospodarczego od tego surowca. Rosnące $\mathrm{z}$ roku na rok ceny ropy naftowej pośrednio spowodowały podwyżkę wielu innych produktów, począwszy od żywności, a kończąc na energii elektrycznej. Rozwiązaniem tego problemu może być poszukiwanie tańszych, alternatywnych źródeł energii, które pozwolą ponownie obniżyć całkowite koszta produkcji, poprzez uniezależnienie się od ropy. Kolejną kwestią wpływającą na rosnące zainteresowanie biopaliwami jest związana z ochroną środowiska możliwość redukcji emisji szkodliwych związków do atmosfery, w tym gazu cieplarnianego, jakim jest ditlenek węgla.

Współczesne silniki spalinowe są konstrukcjami o wysokim poziomie technicznym. Charakteryzują się coraz większą ekonomicznością, a przy tym ich parametry pracy pozostają niezmienne, bądź ulegają poprawie. \akie doskonalenie budowy jednostek możliwe było, gdyż paliwo używane do ich zasilania, zmieniało się przez lata w niewielkim stopniu: ulegało głównie oczyszczaniu ze szkodliwych związków. Aby napędzać silniki paliwami alternatywnymi, bez wprowadzania zmian w ich konstrukcjach, należałoby zbliżyć ich właściwości do właściwości paliw ropopochodnych. Đymczasem tylko niewielka ilość biopaliw gwarantuje prawidłową prace silników. Zmusza to do pójścia inna drogą: dopasowania konstrukcji silników do charakterystyk paliw alternatywnych.

\section{Biodiesel pierwszej generacji}

Stosowane w silnikach ZS biopaliwo w skład którego wchodzą estry metylowe oleju rzepakowego (Polska) lub estry metylowe(FAME) i etylowe(FAEE) 
wyższych kwasów tłuszczowych innych roślin oleistych. Mogą to być zarówno czyste estry jaki i ich mieszanki z olejem napędowym. Najczęstszymi spotykanymi w dystrybucją formami są:

- B100 - 100\% czystych estrów (FAME);

- B20 - mieszanina 20\% estrów (FAME) i $80 \%$ ON;

- B80 - mieszanina 80\% estrów (FAME) i $20 \%$ ON.

Estry wyższych kwasów tłuszczowych otrzymuje się w skali przemysłowej wieloma różnymi metodami. Obecnie najczęściej wykorzystuje się proces transestryfikacji. Polega on na chemicznej wymianie związanej gliceryny w cząsteczce triglicerydu na dodany alkohol metylowy lub etylowy. Całość przebiega w obecności katalizatora, a końcowymi produktami są glicerol i estry, które poddane zostają jeszcze oczyszczaniu. Dla estrów metylowych wyższych kwasów tłuszczowych została określona Polska norma PN-EN 14214:2004, ustalająca wymagania jakie muszą spełnić, aby zostały dopuszczone do użytkowania jako samoistne biopaliwo. Porównanie wymagań jakościowych ON i FAME, wraz z określeniem zgodności przedstawia 凶abela 1.

Tabela 1. Porównanie wymagań jakościowych FAME i ON

\begin{tabular}{|c|c|c|c|c|}
\hline & $\begin{array}{l}\text { Jednostka } \\
\text { miary }\end{array}$ & $\begin{array}{c}\text { ON - } \\
\text { wymagania wg } \\
\text { normy } \\
\text { PN-EN 590:2005 }\end{array}$ & $\begin{array}{c}\text { FAME - } \\
\text { wymagania wg } \\
\text { normy } \\
\text { PN-EN 14214:2004 } \\
\end{array}$ & Zgodność \\
\hline Liczba cetanowa & - & $\min .51,0$ & $\min .51,0$ & $\mathrm{O}$ \\
\hline Indeks cetanowy & - & $\min .46,0$ & & $凶$ \\
\hline Gęstość w temp. $15^{\circ} \mathrm{C}$ & $\mathrm{kg} / \mathrm{m}^{3}$ & $820-845$ & $860-900$ & $\mathrm{X}$ \\
\hline Lepkość w temp. $40^{\circ} \mathrm{C}$ & $\mathrm{mm} 2 / \mathrm{s}$ & $2,0-4,5$ & $3,5-5,0$ & $\mathrm{X}$ \\
\hline $\begin{array}{l}\text { Skład frakcyjny: } \\
\text { - do } 250^{\circ} \mathrm{C} \text { destyluje } \\
\text { - do } 350^{\circ} \mathrm{C} \text { destyluje } \\
\text { - } 95 \% \text { obj. destyluje do temp. }\end{array}$ & $\begin{array}{l}\% \text { obj. } \\
\% \text { obj. } \\
{ }^{\circ} \mathrm{C}\end{array}$ & $\begin{array}{l}\max 65 \\
\min .85 \\
\max 360\end{array}$ & & $凶$ \\
\hline Qemperatura zapłonu & ${ }^{\circ} \mathrm{C}$ & $\min .55$ & $\min .120$ & $\mathrm{O}$ \\
\hline Zawartość siarki & $\mathrm{mg} / \mathrm{kg}$ & $\max 350$ & $\max 10$ & $\mathrm{O}$ \\
\hline Zawartość WWA & $\%(\mathrm{~m} / \mathrm{m})$ & $\max 11$ & & 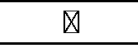 \\
\hline Smarność & $\mu \mathrm{m}$ & $\max 460$ & & 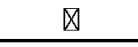 \\
\hline Odporność na utlenianie & $\mathrm{g} / \mathrm{m}^{3}$ & $\max 25$ & & ఐ \\
\hline $\begin{array}{l}\text { Badanie działania korodującego } \\
\text { na płytce miedzi, w } 50^{\circ} \mathrm{C}, 3 \mathrm{~h}\end{array}$ & $\begin{array}{l}\text { stopień } \\
\text { korozji }\end{array}$ & Nr l & Nr l & $\mathrm{O}$ \\
\hline $\begin{array}{l}\text { Pozostałość po koksowaniu (z } 10 \\
\text { \% pozostałości destylacyjne }\end{array}$ & $\%(\mathrm{~m} / \mathrm{m})$ & $\max 0,30$ & $\max 0,30$ & $\mathrm{O}$ \\
\hline Zawartość wody & $\mathrm{mg} / \mathrm{kg}$ & $\max 200$ & $\max 500$ & $\mathrm{X}$ \\
\hline Zawartość zanieczyszczeń & $\mathrm{mg} / \mathrm{kg}$ & $\max 24$ & $\max 24$ & $\mathrm{O}$ \\
\hline \multicolumn{5}{|c|}{$\begin{array}{l}\text { O - wymagania zgodne; } \\
\mathrm{X} \text { - wymagania niezgodne; } \\
\bigotimes \text { - nie uwzględniono badań lub nie przewidziano wymagań; }\end{array}$} \\
\hline
\end{tabular}


W przypadku stosowania 20-30\% mieszaniny estrów z ON, wymagania i metody badań określone zostały w normie zakładowej ZN-05/MGiP/CN-15 „Przetwory naftowe - Paliwa do pojazdów - Biodiesel - Wymagania i metody badań".

Idea wykorzystania olejów roślinnych (OR) do zasilania silników pochodzi od samego Rudolf'a Diesel'a, pierwszego konstruktora silnika ZS. O ile w tamtym czasie zrezygnowano $z$ prac nad pracą silnika na OR na rzecz tańszego i łatwiej dostępnego ON, współcześnie przeprowadzone badania wykluczają użycie olejów roślinnych. Spowodowane jest to jego własnościami fizykochemicznymi, które wymagają poważnych zmian w konstrukcji silnika: nowe tłoki i wtryskiwacze, system kontroli i przemywania układu paliwowego. W przypadku użycia w klasycznym silniku ZS, OR w kontakcie z olejem silnikowym zmienia jego właściwości, co wymagałoby opracowania nowych olejów smarnych. OR powodują również zapiekanie się wtryskiwaczy, a także bardzo utrudniają rozruch silnika w niskich temperaturach. Głównie z tych powodów, podjęto prace nad zastosowaniem pochodnych olejów roślinnych, tj. ich estrów. W kilku procesach chemicznych przeróbki OR uzyskano estry wyższych kwasów tłuszczowych, które okazały się znakomitą alternatywą dla ON. Obecnie wytwarzane estry są już znormalizowane i teoretycznie mogą być używane zamiennie w silnikach ZS. O ile producenci silników w latach 90 nie przewidzieli użycia w ich konstrukcjach paliw alternatywnych, to współcześnie część światowych koncernów nie zaleca używania innych paliw niż ON, często grożąc utratą gwarancji. Producenci dopuszczający zasilanie biodieslem swoich samochodów przedstawieni są w tabeli $2^{1}$.

Tabela 2. Wybrani producenci dopuszczający zasilanie biodieslem silników ZS

\begin{tabular}{|c|c|c|c|}
\hline $\begin{array}{c}\text { Marka } \\
\text { pojazdu }\end{array}$ & $\begin{array}{c}\text { Rodzaj } \\
\text { pojazdu }\end{array}$ & Model & Zakres dopuszczenia \\
\hline Audi & $\begin{array}{c}\text { samochody } \\
\text { osobowe }\end{array}$ & $\begin{array}{c}\text { wszystkie modele QDI } \\
\text { od } 1996 \text { roku }\end{array}$ & \\
\hline BMW & $\begin{array}{c}\text { samochody } \\
\text { osobowe }\end{array}$ & $\begin{array}{c}\text { model } 525 \text { tds1997 } \\
\text { i modele serii } 3 \text { i } 5 \text { od } \\
2001 \text { roku }\end{array}$ & \\
\hline DAF & $\begin{array}{c}\text { samochody } \\
\text { ciężarowe }\end{array}$ & $\begin{array}{c}\text { modele CE75 i CF85 } \\
\text { wyprodukowane po 13 } \\
\text { tygodniu 2001 roku }\end{array}$ & $\begin{array}{c}\text { paliwo musi spełniać wymagania normy } \\
\text { DIN 51606. Należy skrócić do poło- } \\
\text { wy przebieg do wymiany filtru i oleju } \\
\text { silnikowego }\end{array}$ \\
\hline $\begin{array}{c}\text { Daimler- } \\
\text { Chrysler }\end{array}$ & $\begin{array}{c}\text { samochody } \\
\text { ciężarowe }\end{array}$ & $\begin{array}{c}\text { nowe modele, w tym } \\
\text { Actros, Aego, Axor } \\
\text { i Econic }\end{array}$ & $\begin{array}{c}\text { paliwo musi spełniać wymagania normy } \\
\text { DIN 5l606. Zaleca się przemienne } \\
\text { tankowanie } z \text { ON i skrócenie okresu } \\
\text { wymian oleju silnikowego i filtru oleju }\end{array}$ \\
\hline
\end{tabular}

BACZEwski K., KaŁDoński 囚., Paliwa do silników o zapłonie samoczynnym. WKŁ 2004. 


\begin{tabular}{|c|c|c|c|}
\hline Fiatargi & ciągniki & nowe modele & \\
\hline Ford $\mathrm{AG}$ & ciągniki & nowe modele & \\
\hline IVECO & $\begin{array}{l}\text { samochody } \\
\text { ciężarowe }\end{array}$ & niektóre silniki & $\begin{array}{l}\text { nie dotyczy silników z rozdzielaczową } \\
\text { pompą wtryskową. Paliwo zawierające } \\
\text { do } 30 \% \text { biodiesla. Dotyczy pojazdów } \\
\text { komunalnych }\end{array}$ \\
\hline John Deere & ciągniki & $\begin{array}{l}\text { produkowane od } 1987 \\
\text { roku }\end{array}$ & \\
\hline MAN & $\begin{array}{l}\text { samochody } \\
\text { ciężarowe }\end{array}$ & $\begin{array}{l}\text { silniki D08 od nume- } \\
\text { ru } 8953591 \text { i DZ8 od } \\
\text { numeru } 8953001\end{array}$ & $\begin{array}{c}\text { należy zmniejszyć okres wymiany oleju } \\
\text { z } 80000 \mathrm{~km} \text { do } 30000 \mathrm{~km} \text { i gwarancję } \\
\text { na silnik do } 200000 \mathrm{~km}\end{array}$ \\
\hline \multirow{2}{*}{$\begin{array}{l}\text { Mercedes- } \\
\quad \operatorname{Ben} z\end{array}$} & $\begin{array}{l}\text { samochody } \\
\text { osobowe }\end{array}$ & $\begin{array}{l}\text { serie C i E220, C200 } \\
\text { i } 220 \text { CDI }\end{array}$ & \\
\hline & $\begin{array}{c}\text { samochody } \\
\text { dostawcze, } \\
\text { autobusy }\end{array}$ & $\begin{array}{c}\text { serie BR300, } 400, \\
\text { Unimog od } 1988 \text { roku }\end{array}$ & \\
\hline Nissan & $\begin{array}{l}\text { samochody } \\
\text { osobowe }\end{array}$ & Primera od 2001 roku & \\
\hline Renault & $\begin{array}{l}\text { samochody } \\
\text { ciężarowe }\end{array}$ & & $\begin{array}{c}\text { tylko dodatek do ON w ilości do } \\
5 \% \text { odpowiada. DIN } 51606\end{array}$ \\
\hline Seat & $\begin{array}{l}\text { samochody } \\
\text { osobowe }\end{array}$ & serie DI od 1996 roku & \\
\hline Skoda & $\begin{array}{l}\text { samochody } \\
\text { osobowe }\end{array}$ & serie 囚DI od 1996 roku & \\
\hline Steyr & ciągniki & od 1998 roku & \\
\hline Volkswagen & $\begin{array}{l}\text { samochody } \\
\text { osobowe }\end{array}$ & $\begin{array}{l}\text { serie WDI od } 1996 \text { roku, } \\
\text { nowe serie SDI (Euro 3) }\end{array}$ & \\
\hline \multirow{2}{*}{ Volvo } & $\begin{array}{l}\text { samochody } \\
\text { osobowe }\end{array}$ & $\begin{array}{c}\text { serie } \$ 80-D, S 70-\bigotimes D I \\
\text { i V70-凶DI }\end{array}$ & \\
\hline & $\begin{array}{l}\text { samochody } \\
\text { ciężarowe }\end{array}$ & & $\begin{array}{c}\text { toleruje stosowanie RME w ilości do } \\
5 \% \text {. Formalnie nie dopuszcza }\end{array}$ \\
\hline
\end{tabular}

Przeprowadzono wiele badań ${ }^{2,3,4}$, wg. których paliwo złożone w $100 \%$ z FAME, a także ich mieszaniny nie stanowią zagrożenia dla jednostek. Niemniej stwierdzono kilka problemów, które wymagają rozwiązania.

Estry metylowe wykazują właściwości rozpuszczające na materiały zastosowane do produkcji uszczelek i przewodów, które tradycyjnie wykonywane są z gumy, lub tworzyw sztucznych takich jak polistyren, polichlorek winylu, polipropylen ${ }^{5}$. Najbardziej wrażliwe są gumy z kauczuków nitrylo-butadieno-

2 PĄGowski Z., Badania i eksploatacja biopaliw rzepakowych., Instytut Lotnictwa, Warszawa.

3 Gronowicz J., Ochrona środowiska w transporcie lądowym, Instytut 冈echnologii Eksploatacji, Poznań-Radom 2004.

4 Sitnik L., Ekopaliwa silnikowe, Politechnika Wrocławska 2004.

5 Duda A,. Łukasik Z., SKręT J., Kosowicz L., Estry metylowe wyższych kwasów thuszczowych oleju rzepakowego jako paliwo lub komponent olejów napędowych. Paliwa, oleje i smary w eksploatacji, nr 104, 2002 (cz 1) i nr 105, 2003 (cz. 2). 
wych. Należałoby wymienić je na wyprodukowane z kauczuku fluorowego(tzw. VI囚ON). Ma to znaczenie w dłuższym okresie czasu, gdyż w przypadku estrów rozpuszczanie następuje powoli, aczkolwiek może prowadzić do przecieków.

Kolejnym napotkanym problemem wpływającym na prace silnika jest znaczna zmiana lepkości kinematycznej w funkcji temperatury. Zależność ta przedstawiona jest na rys. 1 .

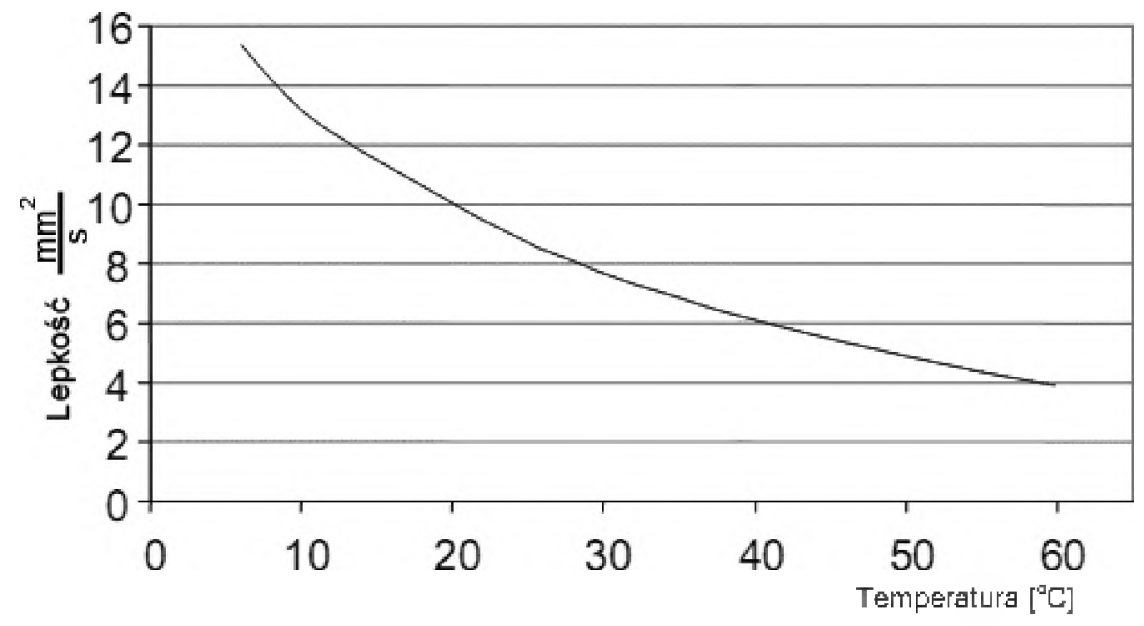

Rys. 1. Wplyw temperatury na lepkość kinematyczna $R M E^{6}$

Charakter takiego przebiegu świadczy o pogorszonych właściwościach niskotemperaturowych. Nie będzie stanowić to problemu w przypadku stosowania RME w okresie przejściowym lub letnim, niemniej zimą może utrudnić bądź uniemożliwić rozruch silnika. Wyższa lepkość wpływa również na pogorszenie przebiegu procesu rozpylania paliwa i podniesienie ciśnienia wtrysku w stosunku do ON o ok. 15\% $\%^{7}$. Związane jest to $\mathrm{z}$ wolniejszym odparowaniem większych kropel paliwa(ok. 1,5 raza niż ON) w komorze spalania, co prowadzi do wydłużenia fazy wstępnej samozapłonu paliwa i ostatecznie przedłużenia czasu spalania. Optymalnym rozwiązaniem byłoby zastosowanie układu wstępnie podgrzewającego paliwo, uruchamianego manualnie lub zautomatyzowanego zależnie od wskazań czujnika temperatury. Wymagałoby to zmiany w obszarze między pompą wtryskową, a wtryskiwaczami, tak by możliwy był poprawny rozruch,

6 Cieślikowski B., Juliszewski 冈., Mazurkiewicz J., Lepkość kinematyczna biopaliwa i fazy glicerynowej. Inżynieria Rolnicza 12/2006, s. 63.

7 Salamour FADI, Procesy zuzycia elementów silnika spalinowego napędzanego paliwami odnawialnymi. Praca doktorska, 1994. 
a także w samym zbiorniku dla dalszej prawidłowej pracy jednostki. O ile rozwiązanie techniczne wymagałoby dość wyraźnych zmian, łatwiejszym sposobem na uzyskanie wymaganych właściwości niskotemperaturowych jest dodawanie specjalnie opracowanych dla FAME depresatorów.

Paliwo FAME charakteryzuje się również odmienną krzywą destylacji niż ON, przedstawioną na rys. 2. Ze względu na prawie jednolity skład chemiczny, temperatura wrzenia FAME zmienia się w niewielkim przedziale wartości. Oznacza to znikomy udział frakcji o niskiej temperaturze wrzenia, co przekłada się na gorsze właściwości rozruchowe.

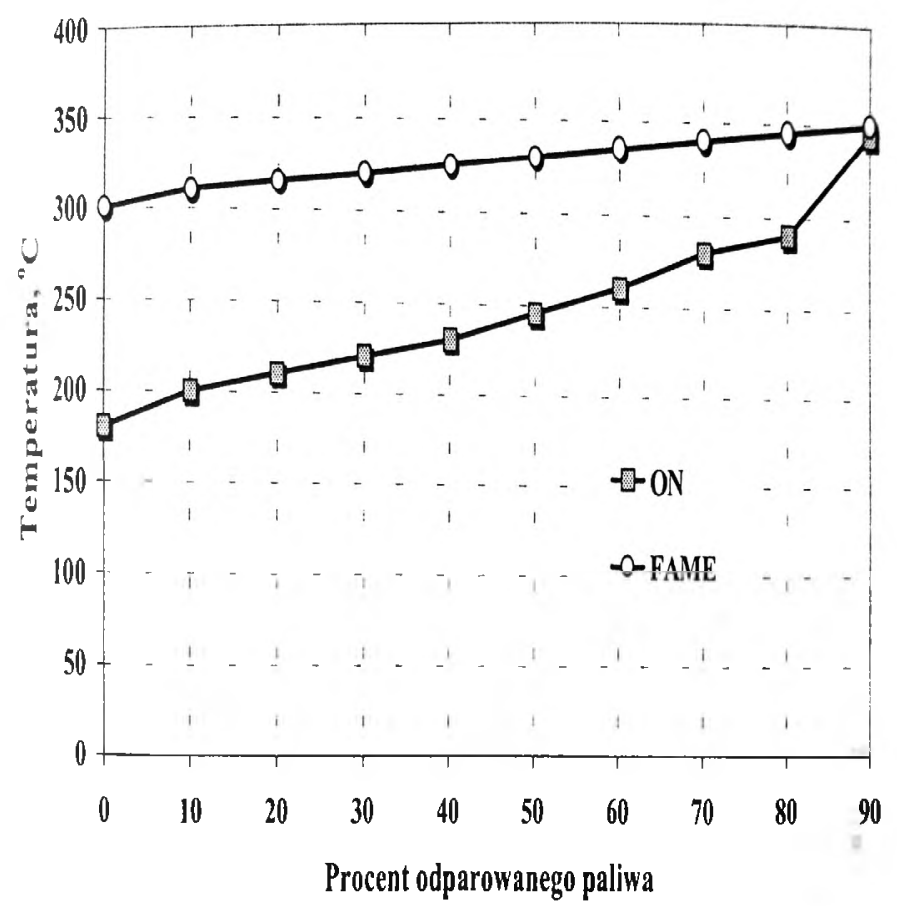

Rys. 2. Krzywa destylacji FAME i $O N^{8}$

Estry zaczynają destylować dopiero w temperaturze $300^{\circ} \mathrm{C}$, co może być przyczyną rozcieńczania oleju smarującego. Nie spalone paliwo wraz z przedmuchami gazów dostaje się do miski olejowej silnika, gdzie w przeciwieństwie do paliwa mineralnego nie odparowuje. Możliwość takiego rozcieńczenia występuje tylko w silnikach z wtryskiem bezpośrednim i nasila się wraz ze wzrostem zużycia sil-

8 SITNIK L., Ekopaliwa silnikowe. Politechnika Wrocławska, 2004. 
nika. Przeprowadzone badania wykluczają jednak to zjawisko jako szkodliwe dla jednostki, jeśli stosowane będą następujące zasady:

- będą stosowane oleje smarowe zalecane przez producentów silników;

- wymiana oleju i filtra będzie dokonywana zgodnie z zaleceniami;

- nagrzewanie po rozruchu zimnego silnika, odbywać się będzie w trakcie jazdy;

- silnik nie będzie pracował długo na biegu jałowym;

Istnieje teoria ${ }^{9}$, nie potwierdzona jednak badaniami, że w systemach „common rail", może dochodzić do przyspieszonej oksydacji estrów, mimo ich wysokiej stabilności na utlenianie. Wiąże się to z przebywaniem paliwa w wysokiej temperaturze $\left(\right.$ ok. $\left.100^{\circ} \mathrm{C}\right) \mathrm{w}$ zasobniku, gdzie pewna część zwracana jest do zbiornika paliwa i narażona zostaje na ponowne działanie tlenu.

Zaznaczyć również należy, że wartość opałowa RME jest niższa o ok. 10\% w stosunku do ON. Przy równocześnie większej gęstości, powoduje to spadek mocy silnika zasilanego RME. Wyrównując tę stratę większą dawką, zwiększa się również jednostkowe zużycie paliwa.

W kwestii emisyjności substancji toksycznych podczas spalania RME istnieje kilka odmiennych zdań. Najprawdopodobniej wiąże się to z przeprowadzaniem badań na silnikach ZS o różnych konstrukcjach. Został wyrażony pogląd ${ }^{10}$, że wartość składników toksycznych jest mniejsza niż ON dla silników starego typu, podczas gdy w nowoczesnych jednostkach wyposażonych w zaawansowane systemy oczyszczania spalin, różnice nie są już tak znaczne. Pomiary ${ }^{11}$ na silniku Citroen'a oznaczonym XUD 9A (stosowanym m.in. w samochodzie Polonez diesel Caro) dały następujące wyniki:

- spadek zadymienia spalin o 50-80\%;

- spadek emisji CO i HC do $40 \%$;

- $\quad$ spadek PM w spalinach $10-60 \%$;

- wzrost emisji NOx o ok. 2-15\%.

W przypadku nowocześniejszego silnika Deutz F3L913, zmiany emisyjności nie były już tak znaczne, co przedstawione jest na rys. 3 .

9 http://www.biofuelsforum.com/using_biodiesel/1569-common_rail_diesel_injection.html

10 Szlachta Z.: Zasilanie silników wysokoprężnych paliwami rzepakowymi. Warszawa, Wydawnictwa Komunikacji i Łączności, 2002. 


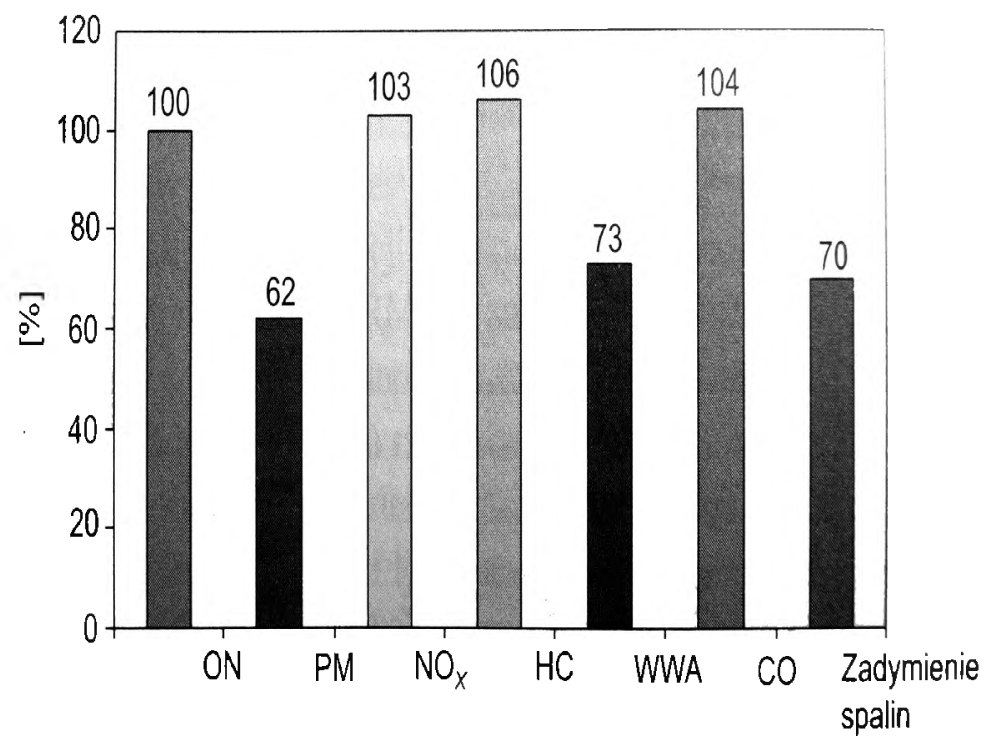

Rys. 3. Względny udział toksycznych składników spalin silnika zasilanego RME $w$ stosunku do zasilania $O N^{12}$

W obu przypadkach zwiększona emisja tlenków azotu wiąże się z obecnością tlenu związanego w grupie estrowej. Najprostszym możliwym sposobem na jej obniżenie może być opóźnienie wtrysku paliwa, co w przypadku RME powinno dać dobry rezultat, gdyż ma on lepsze właściwości samozapłonowe ${ }^{13}$ : jego okres opóźnienia zapłonu jest krótszy niż w przypadku ON o 1-4 stopni OWK.

Podsumowując estry metylowe kwasów tłuszczowych oleju rzepakowego mogą być stosowane jako samoistne paliwo w silnikach ZS, bez przeprowadzania poważniejszych zmian w konstrukcjach. Jedynym znacznym niebezpieczeństwem może okazać się wysoka lepkość w niskich temperaturach.

\section{Bioetanol pierwszej generacji}

Jest to alkohol etylowy otrzymywany z rolniczych surowców odnawialnych, takich jak zboża, buraków cukrowych, ziemniaki. Schemat produkcji bioetanolu można w skrócie przedstawić w trzech etapach:

11 PĄGOWski Z., Badania i eksploatacja biopaliw rzepakowych, Instytut Lotnictwa, Warszawa;

12 Baczewski K., Ka€doński 冈., Paliwa do silników o zaplonie samoczynnym. Warszawa, Wydawnictwa Komunikacji i Łączności, 2004.

13 KaŁdoński 冈., Rajewski M., Szczęch L., Walentowicz J., Przebieg wtrysku i spalania paliwa rzepakowego w silniku o zapłonie samoczynnym. Materialy 5 th International Scientific Conference on Combustion Engines, KONSSPAL 2002, Wrocław, 14-15 maja 2002. 
I. fermentacja alkoholowa glukozy;

II. rektyfikacja;

III. odwadnianie.

Pomysł wykorzystania alkoholu do zasilania silnika spalinowego sięga XIX wieku, kiedy nie odkryto jeszcze technologii rafinacji ropy naftowej. Dla pierwszych silników spalinowych paliwem był właśnie 90-95\% spirytus. Jednak w kolejnych latach, odkrycia złóż ropy naftowej i możliwości jej przeróbki doprowadzily do wyparcia przez nią alkoholu jako paliwa. Spowodowane to było aspektami ekonomicznymi: ropa naftowa była łatwiej dostępna, wydajniejsza energetycznie, a przy tym tańsza. Dopiero kryzys paliwowy lat siedemdziesiątych $\mathrm{XX}$ wieku przyniósł ponowne zainteresowanie paliwami alternatywnymi, $\mathrm{w}$ tym alkoholem. Współcześnie doszła również kwestia na ochrony środowiska i ograniczania korzystania ze złóż naturalnych: użycie biomasy do produkcji alkoholu, nie powoduje istotnego wzrostu ditlenku węgla, głównego gazu cieplarnianego. Emisji $\mathrm{CO}_{2}$ występująca podczas spalania etanolu równoważona jest ilością ditlenku węgla pobieranego przez rośliny w procesie fotosyntezy.

W Europie Bioetanol produkuje się głównie z buraków cukrowych i pszenicy, w Brazylii z trzciny cukrowej, a w USA z kukurydzy. Używany jest jako samoistne paliwo oraz jako biokomponent zarówno w silnikach diesla jak i benzynowych. Zgodnie z normą EN228:2004 (PN-EN 228:2006) jego zawartość w konwencjonalnych benzynach może wynosić do $5 \%$ obj. Od czasu wydania rozporządzenia ${ }^{14}$ bioetanol może być również stosowany do zasilania wybranych flot i wytwarzany przez rolników na własny użytek.

W Polsce do tej pory do paliwa dodawane są pochodne etanolu, najczęściej w postaci eteru etylo-tert-butylowgo (E区BE). Spowodowane jest problemami jakie stwarza bezpośrednie mieszanie etanolu z benzynami: dodatek etanolu powoduje wzrost prężności par, podczas gdy norma PN-EN 228 ogranicza ich wielkość. Również wysoka higroskopijność odwodnionego etanolu utrudnia przechowywanie paliwa, powodując korozję zbiorników. Etanol nie może być wprowadzany do każdej benzyny, lecz tylko do takiej o stosunkowo niskiej prężności par, tak by nie został przekroczony limit narzucony przez normę. Wad tych nie posiadają $\mathrm{E} \otimes \mathrm{BE}$. Możliwe jest dodawanie również eteru metylo-tert-bytulowego ( $\mathrm{M} \otimes \mathrm{BE}$ ), jednak ze względu na większą rozpuszczalność w wodzie i toksyczność w stosunku do E囚BE, praktycznie się go nie stosuje.

Wymagania jakościowe jakie powinien spełniać bioetanol wykorzystywany do komponowania biopaliw ciekłych określone zostały w załączniku do rozpo-

14 Rozporządzenie Ministra Gospodarki z dnia 22 stycznia 2007 r. „W sprawie wymagań jakościowych dla biopaliw ciekłych stosowanych w wybranych flotach oraz wytwarzanych przez rolników na własny użytek". 
rządzenia Ministra Gospodarki z dnia 22 stycznia 2007 r. „w sprawie wymagań jakościowych dla biopaliw ciekłych stosowanych w wybranych flotach oraz wytwarzanych na własny użytek".

W Europie dla bioetanolu jako samoistnego biopaliwa przygotowana została norma EN 15376, a wdrożenie jej planowane jest na rok 2008. Właściwości paliwa zawierającego od 75-85\% bioetanolu określone są w normie CWA 15293:2005.

Najbardziej rozpowszechnionymi paliwami zawierającymi Bioetanol są:

- E10 - biopaliwo zawierające $10 \%$ obj. bioetanolu i $90 \%$ obj. benzyny; oferowane m.in. w USA. Może być stosowane zarówno w samochodach FFV (Flexible Fuel Vehicles) oraz w standardowych pojazdach wyposażonych w silniki benzynowe, które uzyskały dopuszczenie producenta do stosowania takiego paliwa

- E20 - składające się w 20\% z Bioetanol i 80\% benzyny; oferowane głównie w Brazylii do samochodów ZI;

- E85 - paliwo do silników ZI zawierające bioetanol z 15-30\% domieszką benzyny, bez której rozruch silnika w niskiej temperaturze byłby utrudniony; stosowane głównie w Brazylii i USA wyłącznie do pojazdów FFV; w Europie oferowane jest na około 900 stacjach;

- E95 - jest to biopaliwo do silników ZS, składające się w 95\% z Bioetanolu i 5\% dodatków poprawiających jego parametry; ma zastosowanie wyłącznie w dużych, odpowiednio przystosowanych silnikach diesla wykorzystywanych do zasilania samochodach ciężarowych i autobusach; stosowane na małą skalę w Szwecji;

- E100 - paliwo to składa się z samego bioetanolu o czystości 96\%,4\% stanowi woda, która nie może być usunięta w procesie odwodnienia; może być stosowane wyłącznie w klimacie ciepłym.

Etanol obecnie stosowany jest głównie jako paliwo do silników ZI i chociaż może być używany jako samoistne paliwo, nie jest to optymalnym rozwiązaniem. Dające najlepsze rezultaty są mieszaniny benzyny z etanolem w ilości do $85 \%$. Spowodowane jest to właściwościami alkoholu etanolowego, którego duże ciepło parowania, a także mała prężność par utrudnia uruchomienie zimnego silnika w niskiej temperaturze otoczenia. Dodanie $15 \%$ benzyny umożliwia rozruch silnika w temperaturze otoczenia $0^{\circ} \mathrm{C}$. Zmiana wybranych parametrów mieszaniny etanol-benzyna w zależności od udziału etanolu przedstawiona jest na rysunku $4^{15}$.

5 Mayer L., Etanol jako komponent benzyn silnikowych. Auto 囚echnika Motoryzacyjna nr $6 / 1992$. 


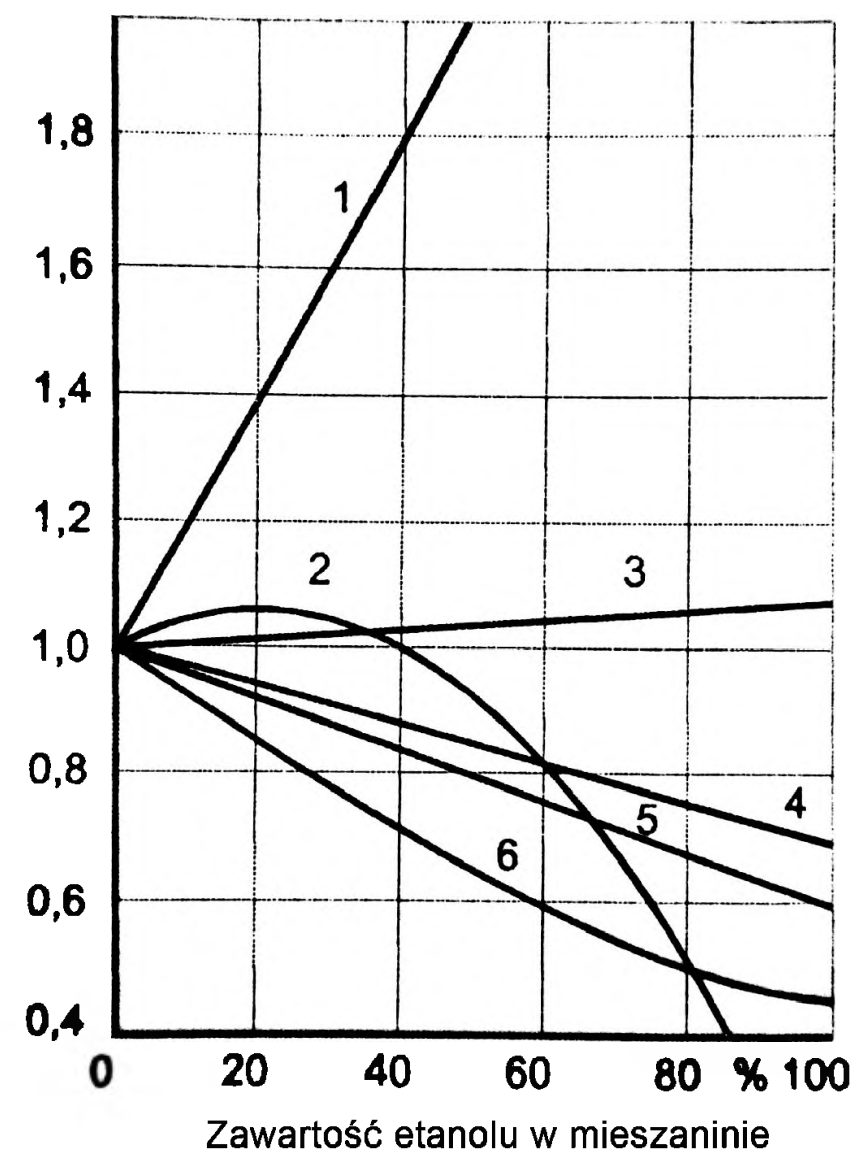

Rys. 4. Względna zmiana wybranych parametrów mieszaniny etanol-benzyna $w$ zależności od udzialu etanolu.

Dostosowanie konstrukcji silników do prawidłowego spalania i bioetanolu, a przy tym zachowaniu parametrów pracy wymaga kilku znacznych zmian w jego budowie. Przykładem silników fabrycznie dostosowanych do spalania paliwa etanolowego są silniki Flexible Fuel Vehicle (FFV)

Dzięki wysokiej liczbie oktanowej bioetanolu, możliwe jest zwiększenie stopnia sprężania silnika, a w konsekwencji uzyskanie większej sprawności. W samochodzie Saab 9-3, zastosowano silnik FFV o nazwie BioPower, który zasilany paliwem E85 o liczbie oktanowej 104, zapewnia wzrost mocy o 17\% i wzrost momentu obrotowego o $10 \% \mathrm{w}$ stosunku do benzyny(LO 95). Najważniejszymi konstrukcyjnymi zmianami jakie zaszły w silnik są: 
- zwiększenie ciśnienie sprężania;

- zastosowanie trwalszych zaworów i ich gniazd;

- zastosowanie odpornych na działanie bioetanolu materiałów w układzie paliwowym;

- zastosowanie czujnika składu paliwa;

- użycie nowoczesnego systemu zarządzania silnikiem, sterującego:

- przepustnicą;

- zapłonem;

- wtryskiem;

- ilością dostarczonego powietrza;

- ciśnieniem doładowania.

Również dostępnym w Europie samochodem, seryjnie przystosowanym do jazdy na bioetanolu i jego mieszaninie jest Ford Focus C-max. \ak jak w przypadku pojazdu marki Saab, zmiany dotyczyły wykonania specjalnie utwardzonych gniazd zaworów i zastosowania płynnej regulacji kąta wyprzedzenia zapłonu, co pozwoliło na prawidłową pracę silnika w zależności od aktualnego składu paliwa. Nowością w silniku Forda jest zastosowanie wstępnego podgrzewania kadłuba silnika, gdy temperatura otoczenia spadnie do $-15^{\circ} \mathrm{C}$.

Nowoczesne FFV jednostki potrafią samoczynnie dostosować się do składu paliwa i na jego podstawie określić parametry regulacyjne. Đymczasem w silnikach, które pierwotnie stworzone były do zasilania tylko benzynami zastosowanie takiego systemu jest czysto nieekonomiczne. Rozwiązaniem będzie tu „stała” zmiana konstrukcyjna, przystosowana do spalania określonej mieszaniny etanolu i benzyny. Zwiększenie stopnia sprężania może uzyskać przez wymianą głowicy na niższą, a przy tym trwalszą, lub/i wymianą łłoków na bardziej wypukłe. Należałoby również zmienić materiał, z którego wykonane są części układu podawania paliwa. W przypadku jednostek gaźnikowych wymagane jest zwiększenie dawki paliwa lub powiększenie średnicy dyszy głównej. Dla silników opartych na wtryskiwaczach trzeba doświadczalnie zmniejszyć kąt wyprzedzenia zapłonu. Wiąże się to $\mathrm{z}$ większą o 20-30\% prędkością spalania etanolu niż benzyny. Zmiany wymaga również zbiornik paliwa: oprócz powiększenia jego pojemności (gdyż wartość opałowa etanolu jest znacznie mniejsza niż benzyny), pompa zasilająca powinna być umieszczona na zewnątrz. W odróżnieniu do benzyny, etanol jest przewodnikiem elektrycznym i mogłoby dojść do jego zapłonu. Używany olej silnikowy powinien posiadać lepsze właściwości dyspergująco-myjące i czas jego pracy do wymiany powinien ulec skróceniu.

Zasilanie silników ZI mieszaniną etanolu i benzyny bez zastosowania żadnych zmian w konstrukcji silnika jest możliwe, gdy ilość etanolu nie przekracza $10 \%$. Przeprowadzono badania ${ }^{16}$ emisyjności pięciu różnych pojazdów zasilanych E10 i otrzymano następujące wyniki:

16 Reading A. H., Norris J. O. W., Feest E. A., Payne E. L.: Ethanol Emission Testing. 
- znacznie zmniejszenie emisji PM i CO;

- dla niektórych testowanych samochodów zanotowano redukcje $\mathrm{CO}_{2}$;

- minimalnie zwiększone zużycie paliwa dla wszystkich pojazdów;

- znikomy wpływ na emisję NOx;

- w przypadku niektórych testowanych samochodów wzrosła emisja acetyloaldehydów.

Inne badania ${ }^{17}$ wykazały, że w przypadku stosowania mieszanek bogatych emisja NOx jest już zauważalna, a jej zmniejszenie można było uzyskać przez opóźnienie zapłonu, a także w warunkach małej prędkości obrotowej i niewielkiego obciążenia. Jednocześnie zaobserwowano obniżenie emisji CO i HC. Jednakże widoczny był znaczny wzrost związków nie uwzględnionych w standardach emisji, głównie aldehydów: w przypadku paliwa E50 emisja aldehydu octowego (etanalu) wzrosła ok. 10 krotnie, a dla paliwa E85 już prawie 20 krotnie; emisja aldehydu mrówkowego(metanalu) wzrosła o ok. 20\%. Potwierdzają to badania ${ }^{18}$ przeprowadzone $w$ teście samochodu Chevrolet Lumina, przedstawione na rysunku 5.

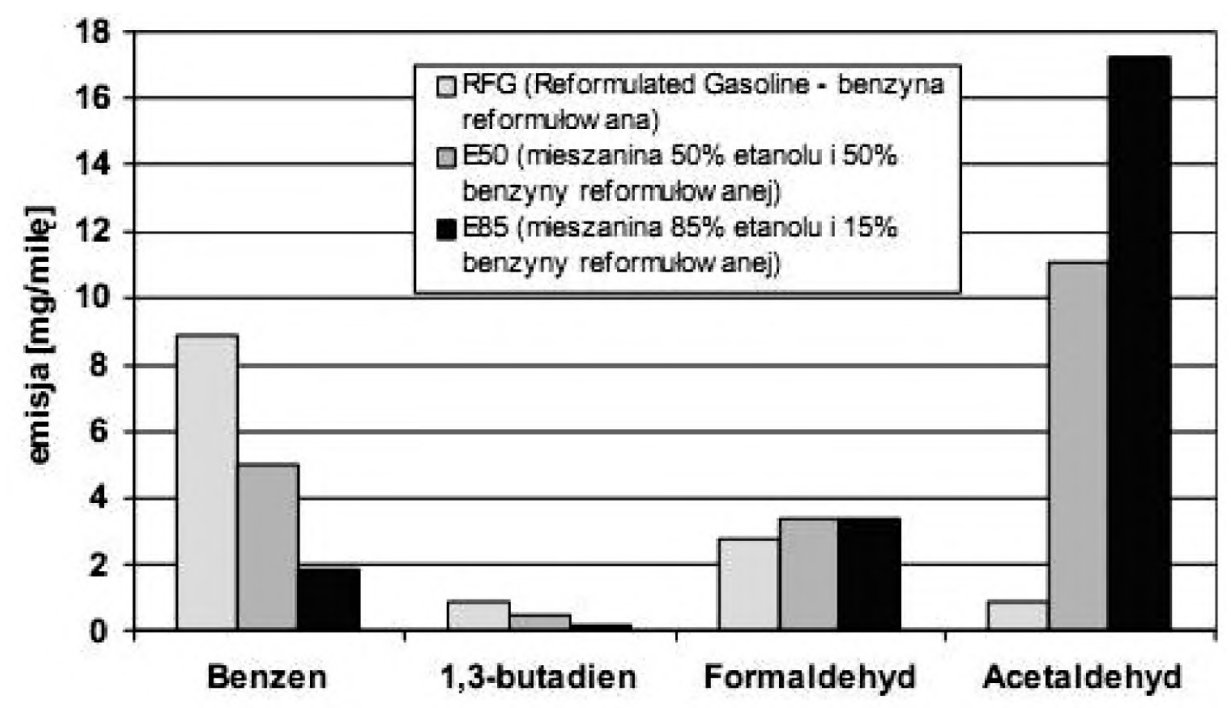

Rys. 5. Emisja toksycznych składników spalin przez samochód Chevrolet Lumina przy zasilaniu paliwami o różnej zawartości etanohu ${ }^{19}$

17 Maćкоwski J., Emisja aldehydów z silników o ZI zasilanych paliwami zawierajacymi związki tlenowe. Paliwa, oleje i smary w eksploatacji nr 91/2001 (cz. 1), nr 92/2001 (cz. 2).

18 Kelly K. J. i inni, Federal Test Procedure Emissions Test Results form Etanol Variable-Fuel Vehicle Chevrolet Lumins. SAE Paper 961092.

19 Merkisz J., Kozak M., Wplyw skladu mieszanek biopaliw z paliwami konwencjonalnymi na emisję toksycznych składników spalin. Eksploatacja I Niezawodność nr 3/2003. 
Zauważyć należy korzystne zmniejszenie emisji benzenu i 1-3 butadienu w stosunku do czystej benzyny.

Stosowanie etanolu staje się coraz powszechniejsze, głównie dzięki odpowiedniej polityce, zapewniającej ulgi podatkowe dla producentów. Również szeroko stosowane obniżanie akcyzy na biopaliwa zachęcają do używania ich jak alternatywnych paliw. Niemniej, aby paliwa oparte o bioetanol mogły stanowić poważna konkurencję dla benzyn, potrzebne jest wsparcie ze strony producentów samochodów, co w konsekwencji doprowadzi do poszerzenia obszaru gdzie takie paliwo będzie dostępne. Na chwile obecną w Europie istnieje około 1000 stacji oferujących bioetanol, głównie jako paliwo E85, z czego ponad 600 znajduje się w Szwecji. Wraz z nowymi technologiami produkcji, prognozuje się ${ }^{20}$, że udział bioetanolu tylko na rynku niemieckim wzrośnie do ponda $2 \mathrm{mln}$. ton w roku 2010.

\section{Dimetyloeter jako paliwo}
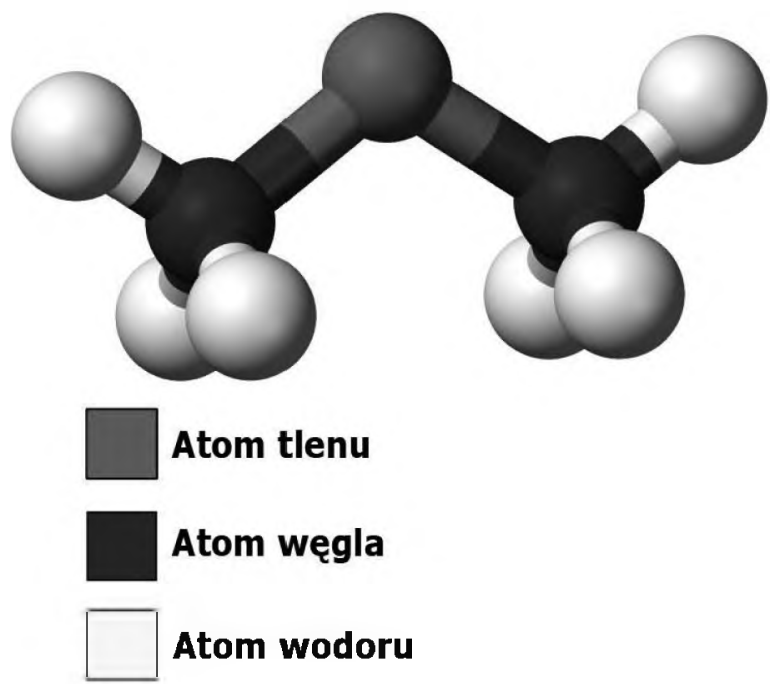

Rys. 6. Budowa przestrzenna czasteczki DME

DME jest najprostszym symetrycznym eterem o budowie przestrzennej, przedstawionej na rys. 6 . Jest to organiczny związek chemiczny z grupy eterów.

20 GraF 冈., Biopaliwa w Niemczech. Wykład przedstawiony na spotkaniu Stowarzyszenia Polskich Cukrowników w Zakopanem. 2006. 
W warunkach normalnych jest bezbarwnym gazem o charakterystycznym zapachu. Łatwo ulega skropleniu pod ciśnieniem 0,5 $\mathrm{MPa}$ w temperaturze $20^{\circ} \mathrm{C}$. Właściwości fizykochemiczne przedstawione są w tabeli 3 . W tabeli 4 porównano właściwości DME z ON.

Najprostszą metodą otrzymywania DME jest dehydratyzacja metanolu, chociaż nie jest to optymalny sposób. Znacznie wydajniejszym procesem jest synteza DMA z biomasy, węgla lub gazu ziemnego, jakkolwiek produkcja DME z substancji stałych, wymaga więcej procesów niż produkcja z gazów. Konieczne jest wtedy zgazowanie biomasy bądź węgla, tak by otrzymać gaz syntezowy. W aspekcie ekologicznym, w trakcie otrzymywania DME z syntezy węgla, emisja ditlenku węgla oceniana jest jako zerowa. Jest to jeden z powodów rosnącego zainteresowania tym paliwem.

Pod względem właściwości fizycznych DME jest podobny do LPG, paliwa stosowanego w silnikach z zapłonem iskrowym. W stosunku do ON, DME posiada kilka bardzo ważnych zalet:

- ma większą liczbę cetanową;

- posiada niską temperaturę wrzenia, dzięki czemu paliwo odparowuje natychmiast po wtrysku;

- spala się bezdymnie;

- charakteryzuje się bardzo niska emisją szkodliwych związków w spalinach.

Tabela 3. Wtaściwości fizykochemiczne $D M E^{21}$

\begin{tabular}{|c|c|c|}
\hline Parametr & Jednostki & Właściwości \\
\hline Względna masa cząsteczkowa & $\mathrm{g} / \mathrm{mol}$ & 46,07 \\
\hline Zawartość węgla & $\%(\mathrm{~m} / \mathrm{m})$ & 52,18 \\
\hline Zawartość wodoru & $\%(\mathrm{~m} / \mathrm{m})$ & 13,04 \\
\hline Zawartość siarki & $\mathrm{Mg} / \mathrm{kg}$ & 0 \\
\hline Zawartość tlenu & $\%(\mathrm{~m} / \mathrm{m})$ & 34,78 \\
\hline $\begin{array}{l}\text { Gęstość względna } \\
\left(15^{\circ} \mathrm{C} / 1 \text { bar }\right)\end{array}$ & - & 1,59 \\
\hline Gęstość (ciecz) & $\mathrm{kg} / \mathrm{m}^{3}$ & 737,7 \\
\hline Lepkość kinematyczna (ciecz) & $\mathrm{mm}^{2} / \mathrm{s}$ & $<1$ \\
\hline Lepkość dynamiczna (ciecz) & $\mathrm{cP}$ & 0,15 \\
\hline Gęstosśc względna w fazie ciekłej $\left(15^{\circ} \mathrm{C} / 1\right.$ bar $)$ & - & 0,66 \\
\hline \emperatura wrzenia (1 bar) & ${ }^{\circ} \mathrm{C}$ & $-24,8$ \\
\hline Demperatura krzepnięcia & ${ }^{\circ} \mathrm{C}$ & $-141,5$ \\
\hline \emperatura zaplonu & ${ }^{\circ} \mathrm{C}$ & -41 \\
\hline
\end{tabular}

21 Gawrońska H., Górski W., Analiza kierunków prac badawczych Centralnego Laboratorium Naftowego na lata 2005 ... 2020 - Eter dimetylowy (DME) jako paliwo silnikowe, Warszawa czerwiec 2005 . 


\begin{tabular}{|l|c|c|}
\hline \emperatura samozapłonu & ${ }^{\circ} \mathrm{C}$ & 235 \\
\hline Liczba cetanowa & - & $55 \ldots 60$ \\
\hline Granice palności par & $\%(\mathrm{~V} / \mathrm{V})$ & $3,4 \ldots 18,6$ \\
\hline Dolna wartość opalowa & $\mathrm{MJ} / \mathrm{kg}$ & $27,6 \ldots 28,8$ \\
\hline Stosunek stechiometryczny powietrze/paliwo & $\mathrm{Kg} / \mathrm{kg}$ & 9,0 \\
\hline $\begin{array}{l}\text { Ciepło parowania } \\
\left(20^{\circ} \mathrm{C} / 1 \text { bar }\right)\end{array}$ & $\mathrm{kJ} / \mathrm{kg}$ & $460 \ldots 470$ \\
\hline Prężność par $\mathrm{w} 20^{\circ} \mathrm{C}$ & bar & 5,1 \\
\hline
\end{tabular}

Tabela 4. Porównanie właściwości DME z ON

\begin{tabular}{|c|c|c|}
\hline Właściwości & DME & ON \\
\hline Wzór chemiczny & $\mathrm{CH}_{3} \mathrm{OCH}_{3}$ & $\mathrm{C}_{y} \mathrm{H}_{y}$ \\
\hline Ciężar cząsteczkowy [g] & 46,07 & $190 \ldots 220$ \\
\hline 囚emperatura wrzenia $[\square \mathrm{C}]$ & $-24,9$ & $180 \ldots 360$ \\
\hline Prężność par wg Reida [MPa] & $0,51 \mathrm{w} 20 \square \mathrm{C}$ & - \\
\hline Gęstość cieczy $\left[\mathrm{kg} \square \mathrm{m}^{-3}\right]$ & 668 & 840 \\
\hline Lepkość dynamiczna cieczy [cP] & 0,15 & $4,5 \ldots 5,4$ \\
\hline Dolna wartość opałowa $\left[\mathrm{MJ} \square \mathrm{kg}^{-1}\right]$ & 28,43 & 42,5 \\
\hline Granice wybuchowości w powietrzu [\% V/V] & $3,4 \ldots 17$ & $0,6 \ldots 6,5$ \\
\hline 囚emperatura zaplonu [ $\square \mathrm{C}]$ & 235 & 250 \\
\hline Liczba cetanowa & $55 \ldots 60$ & $40 \ldots 55$ \\
\hline Stosunek stechiometryczny powietrze/paliwo $\left[\mathrm{kg} \square \mathrm{kg}^{-1}\right]$ & 9,0 & 14,6 \\
\hline Utajone ciepło parowania $\left[\mathrm{kJ} \square \mathrm{kg}^{-1}\right]$ & $460 w-20 \square C$ & 290 \\
\hline Zawartość węgla $[\% \mathrm{~m} / \mathrm{m}]$ & 52,2 & 86 \\
\hline Zawartość wodoru $[\% \mathrm{~m} / \mathrm{m}]$ & 13,0 & 14 \\
\hline Zawartość tlenu $[\% \mathrm{~m} / \mathrm{m}]$ & 34,8 & 0 \\
\hline
\end{tabular}

Obecnie użycie DME jako biopaliwa nie zostało uwzględnione w żadnej normie, istniejące uregulowania dotyczą stosowania go wyłącznie w aerozolach. Zadaniu opracowania znormalizowanych wymagań dla DME jako paliwa silnikowego podjęło się Japońskie Forum DME i Podkomitet ISO/囚C 28/SC4.

Idea zastosowania DME jako paliwa silnikowego jest dość świeża. W roku 1992 Haldor \opsle odkrył, że pewne właściwości DME pozwalają na wydajne użycie go w silniku ZS. Wysoka liczba cetanowa i niska temperatura wrzenia (co przekłada się na szybkie odparowanie) stały się podstawą do stworzenia tezy, że DME w przyszłość będzie mogło stanowić mocną konkurencję dla ON. Również ze względu na strukturę chemiczną i duża zawartość tlenu w cząsteczce, spalanie DME dawało pewność znacznego obniżenia emisji cząstek stałych, a w przypadku emisji NOx możliwe będzie zastosowanie wyższego poziomu EGR. 
Istotną zaletą DME jest znikoma toksyczność dla człowieka. Według przeprowadzonych badań ${ }^{22}$ nie zagraża on zdrowiu człowieka. Również potencjał do tworzenia ozonu ma niższy niż LPG i węglowodory zawarte w benzynie ${ }^{23}$.

Niestety, użycie DME w silniku wysokoprężnym wymaga odpowiedniego przebudowania układu zasilania i nie jest to takie proste jak początkowo zakładano. W warunkach atmosferycznych eter dimetylowy jest w stanie gazowym, jednak żeby możliwy wtrysk odpowiedniej dawki, wymagane jest sprężenie go do postaci ciekłej. Problem stanowi również bardzo mała lepkość cieczy (ok. 30 razy mniejsza niż ON): ze względu na prześwity w układzie wtryskowym i smarującym może powodować przecieki; w przypadku mieszania się z olejem smarowym doprowadzi do zwiększonej emisji cząstek stałych. Wadą DME jest również jego mała smarność, którą można jednak poprawić stosując dodatek smarnościowy.

Obecnie rozważa się dwa sposoby przystosowania silnika ZS do zasilania przez DME. W jednostkach małej mocy i pojemności (do 0,5 l. objętości cylindra) możliwe byłoby zastosowanie podwójnego systemu podawania paliwa. Wymaga to jednak zmian w konstrukcji podobnych do tych, jakie stosowane są przy zasilaniu LPG instalacją piątej generacji. Adaptacja taka jest bardzo trudna z powodu wysokich wymagań niezawodności i potrzebne są badania trwałości takiego układu. Drugim rozwiązaniem jest opracowywany specjalny system wtrysku bazujący na popularnym układzie „common rail". \aka konstrukcja mogłaby być zastosowana już w jednostkach dużej mocy i zapewniłaby odpowiednią szczelność układu. DME nie wymaga wysokiego ciśnienia wtrysku (do 300 barów) oraz nie ma potrzeby jego gwałtownego końca wtrysku, co pozwoliłoby na zastosowanie zaworów solenoidowych. W rezultacie osiągnięty zostałby wymagany poziom kontroli wtrysku i zachowane zostałyby względy bezpieczeństwa.

System doświadczalnego układu zasilania silnika ZS dla DME przedstawia rysunek $7^{24}$

22 DuPont, 囚oxicity summary for dimethyl ether (DME) DYMEL a propelant: 囚echnical Information, ADS-1.

23 Gray C., Webster G., A Study of Dimethyl Ether (DME) as an Alternative Fuel for Diesel Engine Applications. Advancet Engine Technology Ltd. Raport 囚P 13788E; Kanada, maj 2001.

24 Gawróśska H., Górski W., Eter dimetylowy (DME) jako paliwo silnikowe, Analiza kierunków prac badawczych centralnego laboratorium naftowego na lata 2005 ... 2020, Warszawa 2005. 


\section{Schemat zasilania DME}

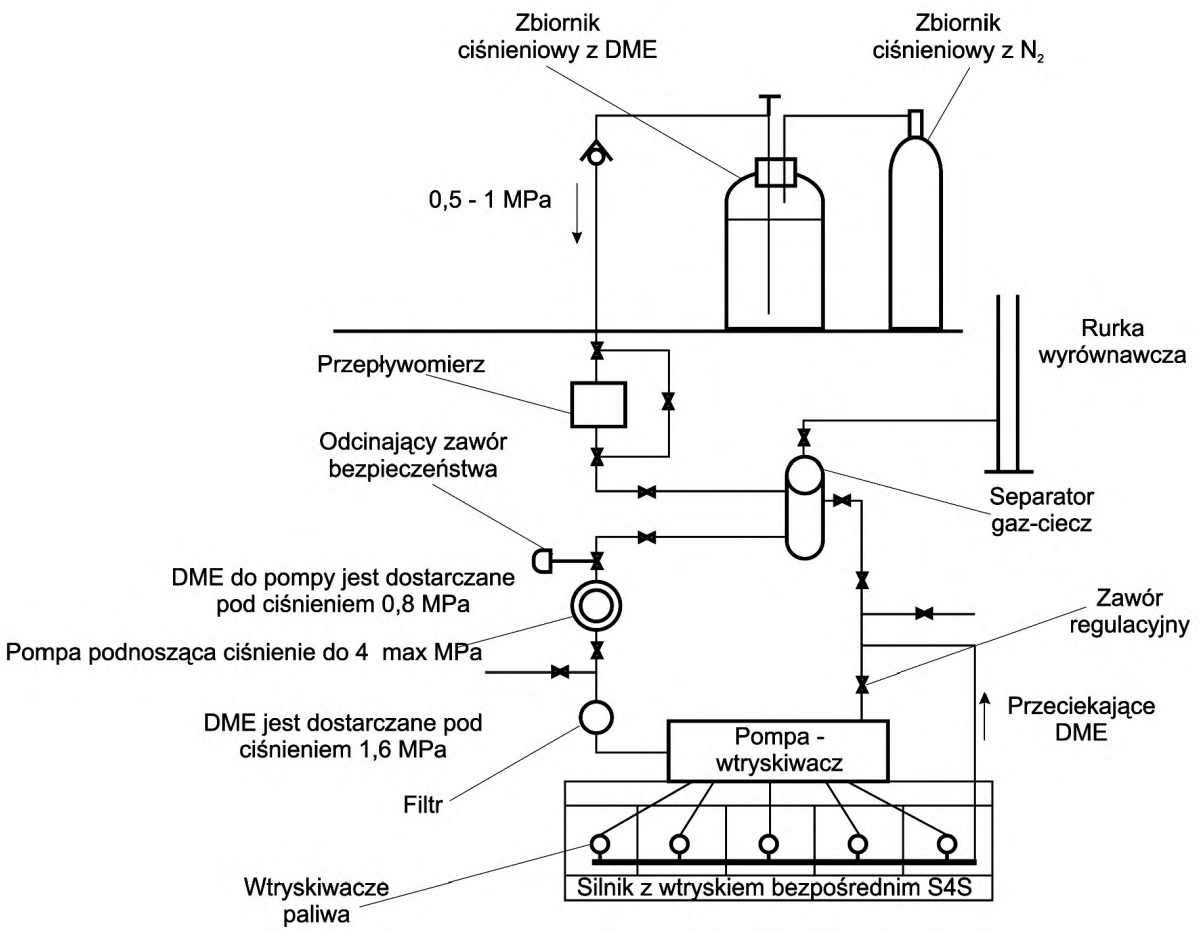

Rysunek 7. Schemat zasilania DME

Aby zapobiec tworzeniu się korków gazowych i powstawaniu zjawiska kawitacji w przewodach wymagane jest ciśnienie podawania paliwa w granicach 12-30 bar. Wszelkie uszczelnienia powinny być wykonane z polimerów opartych na związkach fluoru. Aby uzyskać taką samą zawartości energii w zbiorniku względem ON, wymagane jest powiększenie go o 66\%, co po uwzględnieniu różnicy w gęstości paliwa da około $20 \%$ przyrost masy zbiornika.

Oprócz wymogów prawidłowej i niezawodnej pracy systemu paliwowego, wobec DME stawiane są wymagania względem składu spalin tak zasilanego sinika. Przy założeniu prawidłowo pracującego systemu wtrysku, podczas spalania eteru dimetylowego powstaje bardzo mała ilość cząstek stałych i tlenku węgla. \oksyczność spalin wydalanych przez silnika zasilane DME osiągają poziomy wymagane przez kalifornijską normę dla pojazdów o bardzo niskiej emisji (ULEV), co przedstawione jest na rysunku $8^{25}$.

25 Baczewski K., Ka£doński \., Paliwa do silników o zapłonie samoczynnym. Warszawa, Wydawnictwa Komunikacji i Łączności, 2004. 


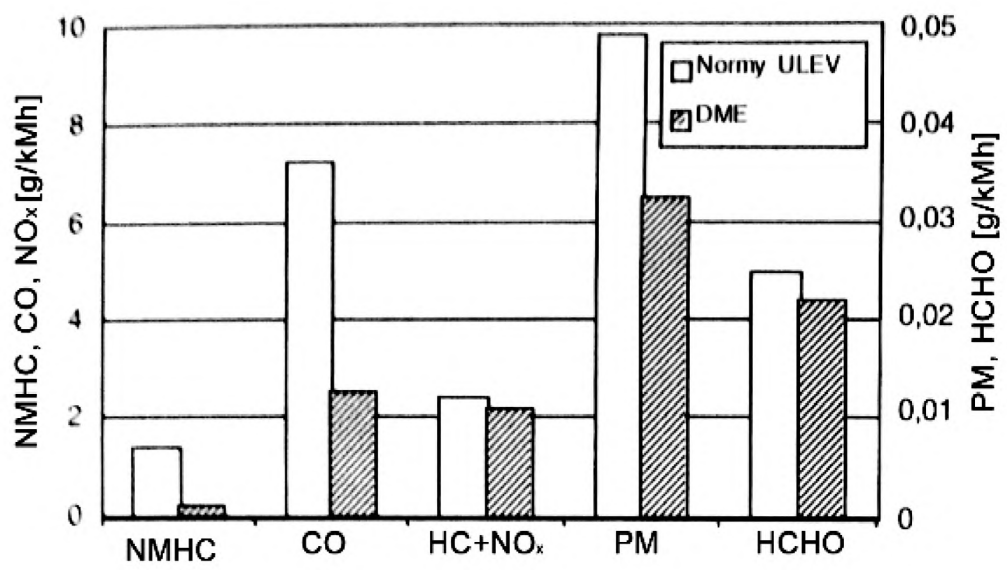

Rysunek 8. Emisja związków toksycznych silnika zasilanego DME na tle normy dla pojazdów ULEV.

Redukcja NOx może być osiągnięta poprzez opóźnienie czasu wtrysku i wysoki poziom recyrkulacji spalin. Również właściwości DME idealnie pasują do zastosowania nowoczesnej technologii homogenicznego spalania(HCCI), co pozwoli na dalsze zmniejszenie emisji tlenków azotu, a także redukcję zużycia paliwa.

Badając skład spalin na silniku eksperymentalnym uzyskano lepsza sprawność cieplną dla niskich i średnich obciążeń. Przy wysokim obciążeniu, z powodu dłuższego czasu wtrysku i wolniejszego spalania, sprawność cieplna była nieznacznie niższa. DME charakteryzuje się również spalaniem bezdymnym w każdych testowych warunkach. Szczegółowe wyniki przedstawione są na rysunku $9 .^{26}$

26 Pana C., Negurescu N., Popa M.G., Boboc G., Cernat AI.: Performance of a DME Fueled Diesel Engine - FUELS, 5th International Colloquium, January 12-13, 2005, 冈echnische Akademie Esslingen Wwiterbildungszentrum, Germany. 

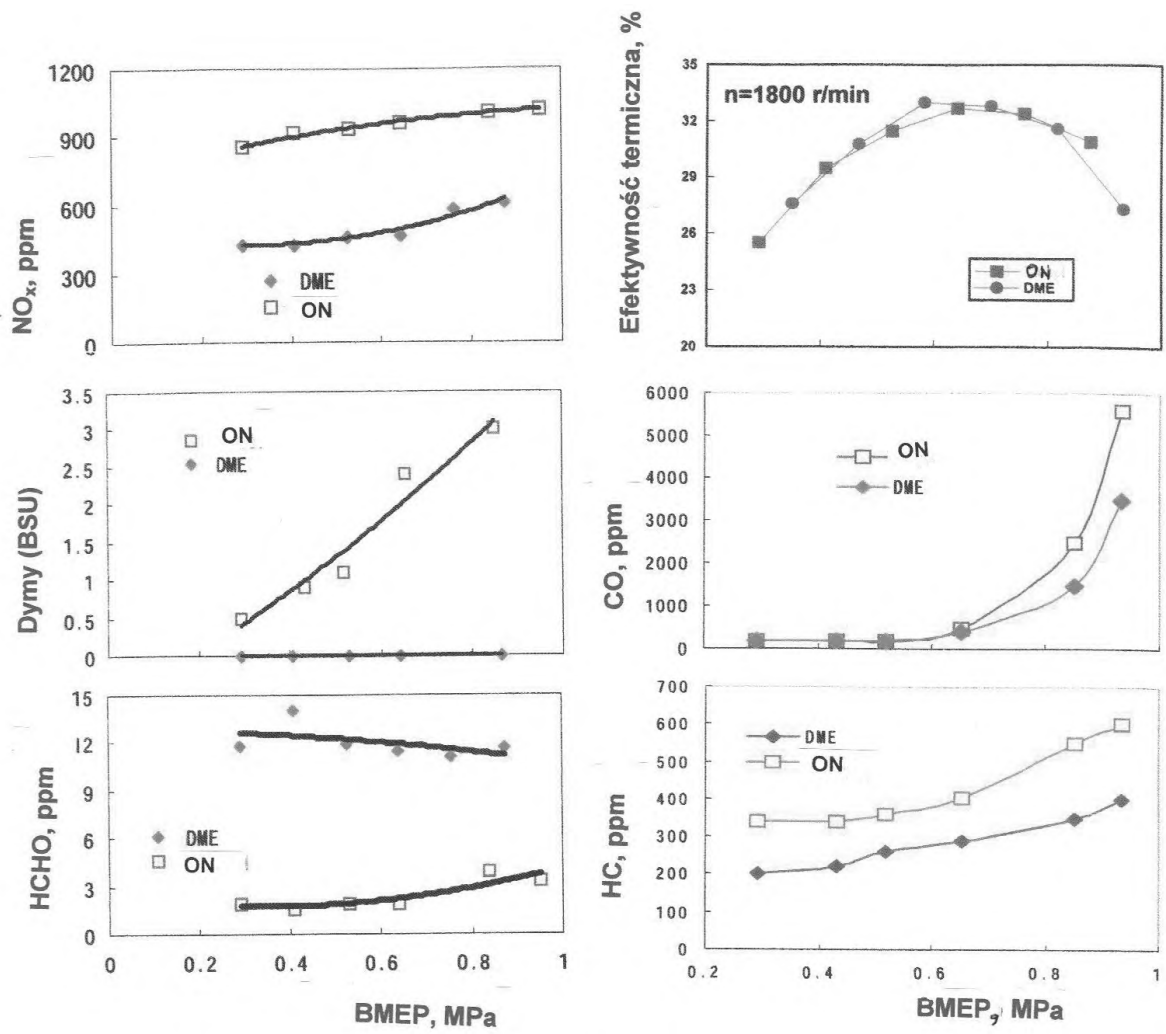

Rysunek 9. Porównanie charakterystyk emisji DME $i$ ON w funkcji średniego efektywnego ciśnienia użytecznego(BMEP) (n=1800 r.min)

Średnie efektywne ciśnienie użyteczne jest miarą pozwalającą porównać osiągi różnych silników. Obliczane jest na podstawie momentu obrotowego i pojemności skokowej, jednakże nie jest to aktualne ciśnienie w cylindrze. W przypadku przedstawiania charakterystyk w funkcji BMEP, pozwalają one ocenić dany wynik w zależności od obciążenia silnika.

Reasumując, eter dimetylowy ma potencjał bycia paliwem mocno konkurencyjnym dla oleju napędowego. Uzyskiwanie znakomitych wyników w kwestii emisyjności związków toksycznych to główny czynnik rosnącego zainteresowania tym paliwem. Dla DME otrzymywanego z biomasy, emisja $\mathrm{CO}_{2}$ jest niższa o $80 \%$ w cyklu W区 $\mathrm{W}^{27}$, chociaż metody produkcji DME pozostają jeszcze na wczesnym etapie. Problem skonstruowania optymalnego systemu podawania paliwa nale-

27 Gawrońska H., Górski W., Eter dimetylowy (DME) jako paliwo silnikowe, Analiza kierunków prac badawczych centralnego laboratorium naftowego na lata 2005...2020, Warszawa 2005. 
ży do producentów, gdyż prace związane z przystosowaniem silnika do spalania DME muszą zajść na wczesnym etapie jego budowy. Niemniej można wysunąć twierdzenie, że mimo napotkanych problemów eter dimetylowy może świetnie służyć w przyszłości jako paliwo alternatywne. Wymaga to jednak dalszych, intensywnych badań i mocniejszego wsparcia ze strony państw zainteresowanych wdrażaniem paliw niekonwencjonalnych.

\section{Wnioski}

Estry metylowe obecnie stanowią dobre paliwo zastępcze dla ON i przy niewielkich kosztach adaptacji, można nimi zasilać praktycznie każdy silnik ZS. Znaczna redukcja emisji PM, CO i HC przy zasilaniu silników estrami, a także zbliżone właściwości fizykochemiczne do ON, przemawiają na korzyść FAME. Bardzo ważnym aspektem, uwzględnianym w ocenie biopaliwa są jego możliwości magazynowania i dystrybucji. W przypadku estrów wymagana jest większa szczelność zbiorników w których są przechowywane, ale za to cały system dystrybucji może opierać się na tym wykorzystywanym do ON. Istotną wadą jest stosunkowo niewielki dopuszczalny okres magazynowania On z dodatkiem FAME.

W przypadku zastosowania bioetanolu, wymagania względem konstrukcji są już większe. Związane jest to głownie ze zmianą materiału z jakich wykonane są niektóre podzespoły silnika. Bioetanol wymaga również ponownej regulacji charakterystyki pracy silnika. Jednakże dla paliwa zawierającego do $10 \%$ etanolu, badania wykazały że konstrukcja może pozostać niezmieniona. Jest to sposób na osiągniecie założonych poziomów NCW, chociaż ciągle brakuje przepisów pozwalających na dystrybucję takiego paliwa dla pojazdów nie należących do oznaczonych flot.

Eter dimetylowy wydaje się najbardziej przyszłościowym paliwem do silników działających na zasadzie samozapłonu. Rosnące zainteresowanie wykorzystaniem DME jako paliwa, związane jest z jego bardzo niską emisyjnością - jest obecnie najczystszym paliwem alternatywnym. Niestety, przystosowanie współczesnych silników ZS jest bardzo trudne, a przez to nieopłacalne. Rozwiązaniem powinny być tu dalsze badania i testy, przeprowadzane we wspólpracy z producentami silników. W przyszłości rozwiązania wymagać będzie sposób dystrybucji, chociaż już teraz można przypuszczać, że będzie podobny do LPG.

Wdrażanie biopaliw wymaga wielu działań, nie tylko ze strony państwa. Odpowiednie nastawienie światowych koncernów motoryzacyjnych, wspierających badania i dalszy rozwój silników przystosowanych do spalania biopaliw, powinno doprowadzić do szybkiego wprowadzenia ogólnodostępnych modeli samochodów z takimi silnikami. Dotyczyć to powinno głownie tych paliw, które obecnie nie mogą być stosowane w tradycyjnych konstrukcjach, a ich adaptacja jest nieopłacalna. 


\section{LI冈ERA囚URA}

BACZEwSKI K., KA£DoŃski 囚.: Paliwa do silników o zaplonie samoczynnym. WKE 2004

Cieślikowski B., Juliszewski 囚., Mazurkiewicz J.: Lepkość kinematyczna biopaliwa i fazy glicerynowej. Inżynieria Rolnicza 12/2006, s 63.

Duda A,. ŁuKasik Z., SKRĘT J., Kosowicz L.: Estry metylowe wyższych kwasów thuszczowych oleju rzepakowego jako paliwo lub komponent olejów napędowych. Paliwa, oleje i smary w eksploatacji, nr 104, 2002 (cz 1) i nr 105, 2003 (cz. 2)

DuPONT: Toxicity summary for dimethyl ether (DME) DYMEL a propelant: Technical Information, ADS-1;

Gawrońska H., Górski W.: Analiza kierunków prac badawczych Centralnego Laboratorium Naftowego na lata 2005 ... 2020 - Eter dimetylowy (DME) jako paliwo silnikowe, Warszawa czerwiec 2005.

Graf Q.: Biopaliwa w Niemczech. Wykład przedstawiony na spotkaniu Stowarzyszenia Polskich Cukrowników w Zakopanem. 2006

Gray C., Webster G.: A Study of Dimethyl Ether (DME) as an Alternative Fuel for Diesel Engine Applications. Advancet Engine 冈echnology Ltd. Raport 冈P 13788E; Kanada, maj 2001.

Gronowicz J., Ochrona środowiska w transporcie lądowym, Instytut \echnologii Eksploatacji, Poznań-Radom 2004.

Internet: http://www.biofuelsforum.com/using_biodiesel/1569-common_rail_diesel_injection. html

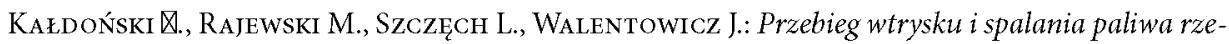
pakowego $w$ silniku o zaplonie samoczynnym. Materiały 5th International Scientific Conference on Combustion Engines, KONSSPAL 2002, Wrocław, 14-15 maja 2002.

Kelly K. J. i inni: Federal Test Procedure Emissions Test Results form Etanol Variable-Fuel Vehicle Chevrolet Lumins. SAE Paper 961092.

MAćKowski J.: Emisja aldehydów z silników o ZI zasilanych paliwami zawierającymi związi tlenowe. Paliwa, oleje i smary w eksploatacji nr 91/2001 (cz. 1), nr 92/2001 (cz. 2).

MAYER L.: Etanol jako komponent benzyn silnikowych. Auto \echnika Motoryzacyjna nr 6/1992.

Merkisz J., KozaK M.: Wplyw składu mieszanek biopaliw z paliwami konwencjonalnymi na emisje toksycznych składników spalin. Eksploatacja I Niezawodność nr 3/2003.

Pana C., Negurescu N., Popa M.G., Boboc G., Cernat AI.: Performance of a DME Fueled Diesel Engine- FUELS, 5th International Colloquium, January 12-13, 2005, 冈echnische Akadem.

PĄGOWSKI Z.: Badania i eksploatacja biopaliw rzepakowych, Instytut Lotnictwa, Warszawa.

Reading A. H., Norris J. O. W., Feest E. A., Payne E. L.: Ethanol Emission Testing.

Rozporządzenie Ministra Gospodarki z dnia 22 stycznia 2007 r. „W sprawie wymagań jakościowych dla biopaliw ciekłych stosowanych w wybranych flotach oraz wytwarzanych przez rolników na własny użytek".

Salamour Fadi: Procesy zużycia elementów silnika spalinowego napędzanego paliwami odnawialnymi. Praca doktorska, 1994.

SitNiK L., Ekopaliwa silnikowe, Politechnika Wrocławska 2004.

SzLACHTA Z.: Zasilanie silników wysokoprężnych paliwami rzepakowymi. Warszawa, Wydawnictwa Komunikacji i Łączności, 2002.ie Esslingen Wwiterbildungszentrum, Germany. 


\title{
Title: Problems in supplying modern internal combustion engine with biofuels
}

\begin{abstract}
SUMMARY
The paper presents most popular biofuels with their basic physicochemical properties in comparison with conventional fuels. The article also contains present normalizations of selected alternative fuels. The possibilities of supplying modern internal combustion engine with biofuels with requiring changes in their constructions were estimated on the basis of collected documentation.
\end{abstract}

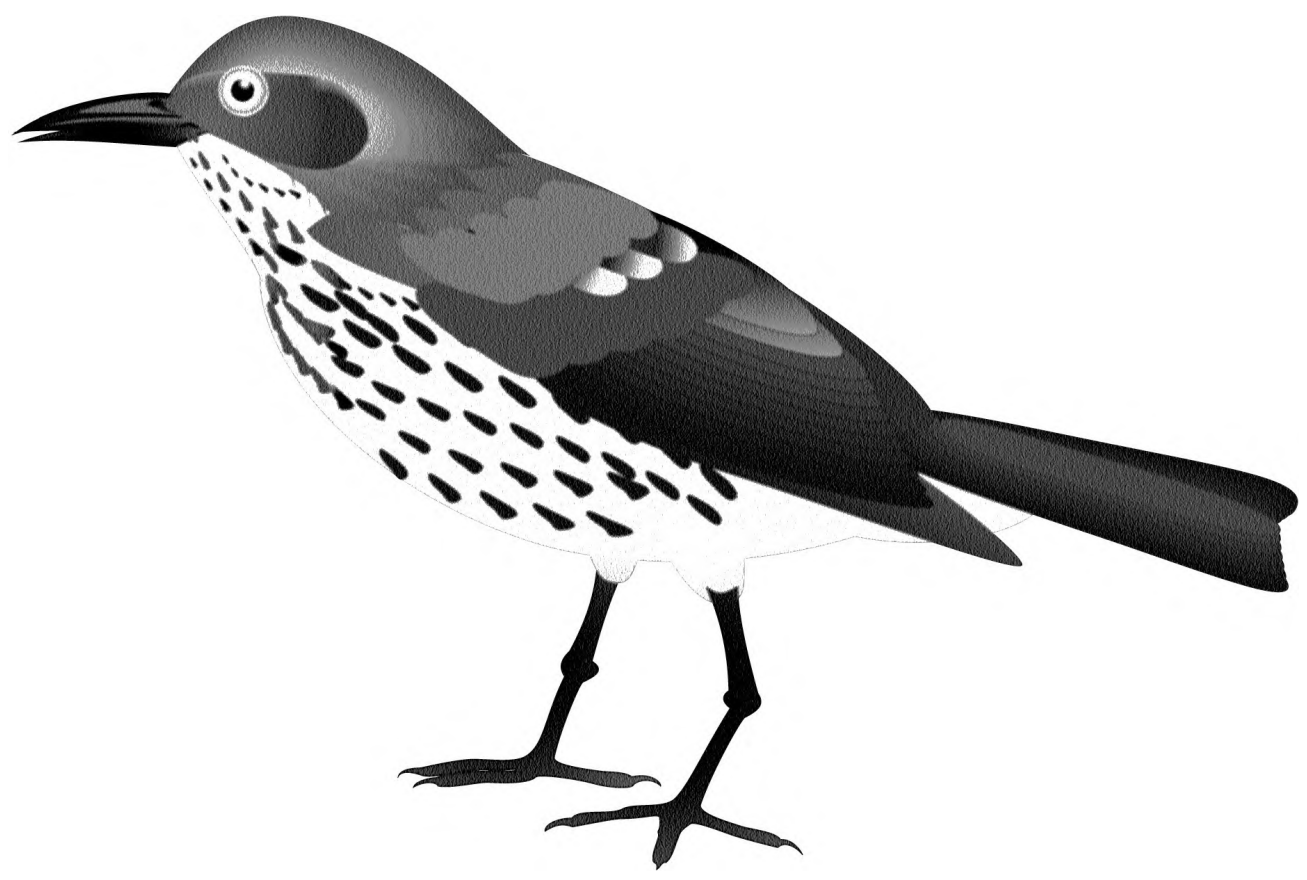

